IMPERFECT ORACLE 
In this place I am minded to build a glorious temple to be an oracle for men, and here they will always bring perfect hecatombs, both they who dwell in Peloponnesus and the men of Europe and from all the wave-washed isles, coming to question me. And I will deliver to them all counsel that cannot fail, answering them in my rich temple.

HOMER, HYMN TO PYTHIAN APOLLO, TRANS. EVELYN WHITE 


\section{IMPERFECT ORACLE}

THE EPISTEMIC AND MORAL AUTHORITY OF SCIENCE

Theodore L. Brown 


\section{Library of Congress Cataloging-in-Publication Data}

Brown, Theodore L. (Theodore Lawrence), I928Imperfect oracle : the epistemic and moral authority of science/Theodore L. Brown.

p. $\mathrm{cm}$.

Summary: "Explores the relationships between science and other societal sectors, notably law, religion, government and public culture, in terms of the concepts of expert and moral authority"-Provided by publisher.

Includes bibliographical references and index. ISB N 978-0-27I-03535-2 (cloth : alk. paper) I. Science-Moral and ethical aspects. 2. Science-Social aspects. I. Title.

$$
\begin{gathered}
\text { QI80.55.M67B76 } 2009 \\
\text { I74'.95-dc22 } \\
2009000901
\end{gathered}
$$

Copyright (C) 2009 The Pennsylvania State University

All rights reserved

Printed in the United States of America

Published by The Pennsylvania State University Press,

University Park, PA I6802-1003

It is the policy of The Pennsylvania State University Press

to use acid-free paper. This book is printed on Natures Natural, containing $50 \%$ post-consumer waste, and meets the minimum requirements of American National Standard for Information SciencesPermanence of Paper for Printed Library Material, ANSI Z39.48-I992. 
for AUDREY 
